\title{
Butenolide and Furandione from an Endophytic Aspergillus terreus
}

\author{
Paulwatt Nuclear, ${ }^{a}$ Damrong Sommit, ${ }^{b}$ Nattawut Boonyuen, ${ }^{c}$ and Khanitha PudHom ${ }^{*, d}$ \\ ${ }^{a}$ Program in Biotechnology, Faculty of Science, Chulalongkorn University; ${ }^{d}$ Research Centre for Bioorganic Chemistry, \\ Department of Chemistry, Faculty of Science, Chulalongkorn University; Bangkok 10330, Thailand: ${ }^{b}$ Department of \\ Chemistry, Faculty of Science, Mahanakorn University of Technology; Bangkok 10530, Thailand: and ${ }^{c}$ National Center \\ for Genetic Engineering and Biotechnology (BIOTEC); 113 Thailand Science Park, Pathumthani 12120, Thailand. \\ Received February 16, 2010; accepted June 3, 2010; published online June 25, 2010
}

\begin{abstract}
A new butenolide, aspernolide D (1), and furandione, asperterone (2), together with four known butenolides, butyrolactones I-IV and aspernolide B, were obtained from cultures of the endophytic fungus Aspergillus terreus, isolated from the flowering plant Mammea siamensis. The structures of these compounds were elucidated by analysis of NMR spectroscopic and mass spectrometric data.
\end{abstract}

Key words $\quad$ butenolide; furandione; Aspergillus terreus

Endophytic fungi have proved to be a rich source of bioactive secondary metabolites, ${ }^{1,2)}$ and recently several novel bioactive substances have been isolated from these microorganisms. $^{3-5)}$ Aspergillus terreus has been isolated from both marine and terrestrial sources and is well known for the production of butenolides. In the course of our search for biologically active metabolites from endophytic fungi from Thai medicinal plants, a subculture of an isolate of A. terreus, obtained from the leaves of Mammea siamensis, was cultivated in medium containing corn steep liquor. We report here the isolation and structural elucidation of a new butenolide, aspernolide D (1), and furandione, asperterone (2), together with four known butenolides, butyrolactones $\mathrm{I}-\mathrm{IV}^{6,7)}$ and aspernolide $\mathrm{B},{ }^{8)}$ and the evaluation of compounds $\mathbf{1}$ and $\mathbf{2}$ for their antibacterial activity against both Gram-positive and Gram-negative bacteria. To the best of our knowledge, this is the first report of butyrolactone III from a natural source.

\section{Results and Discussion}

The EtOAc crude extract of the culture broth of $A$. terreus RCBC 1002 was successively subjected to Sephadex LH20 and silica gel column chromatography to afford butyrolactones I and II as major constituents. Compounds $\mathbf{1}$ and $\mathbf{2}$ (Fig. 1), as well as butyrolactones III, IV, and aspernolide B, were isolated as minor metabolites according to TLC analyses.

Aspernolide D (1) was isolated as a light yellow gum and its molecular formula was assigned to be $\mathrm{C}_{24} \mathrm{H}_{26} \mathrm{O}_{9}$ based on high resolution-electrospray ionization (HR-ESI)-MS analysis $\left(\mathrm{m} / \mathrm{z} 481.1472[\mathrm{M}+\mathrm{Na}]^{+}\right.$, Calcd 481.1475), indicating 12 degrees of unsaturation. IR absorptions at 3443 and $1697 \mathrm{~cm}^{-1}$ implied the presence of hydroxyl and carbonyl groups, respectively. The ${ }^{1} \mathrm{H}-\mathrm{NMR}$ spectrum (Table 1) showed the signals of two methyls at $\delta_{\mathrm{H}} 1.12$ and 1.27 , a methoxy group at $\delta_{\mathrm{H}} 3.67$, and of an $\mathrm{A}_{2} \mathrm{~B}_{2}$ system at $\delta_{\mathrm{H}} 6.90$ $(\mathrm{d}, J=8.8 \mathrm{~Hz}$ ) and $7.60(\mathrm{~d}, J=8.8 \mathrm{~Hz})$, indicating the presence of a para-disubstituted benzene ring. Another three aromatic signals at $\delta_{\mathrm{H}} 6.47(\mathrm{~d}, J=8.4 \mathrm{~Hz}), 6.54(\mathrm{~d}, J=8.4 \mathrm{~Hz})$, and 6.64 (s) were suggestive of the existence of an additional unsymmetrical trisubstituted benzene ring in the molecule. Analysis of the ${ }^{13} \mathrm{C}$-NMR spectrum and the information from 2D NMR studies $\left({ }^{1} \mathrm{H}-{ }^{1} \mathrm{H}\right.$ correlation spectroscopy (COSY), heteronuclear single quantum coherence (HSQC), and heteronuclear multiple bond connectivity (HMBC)) revealed the presence of 10 aromatic carbon resonances for two benzene moieties, an ester carbonyl $\left(\delta_{\mathrm{C}} 169.4\right)$, tetrasubstituted olefinic carbons $\left(\delta_{\mathrm{C}} 128.2,137.4\right)$, two methylenes $\left[\delta_{\mathrm{H}} 2.97\right.$ $\mathrm{m}, \delta_{\mathrm{C}} 30.5 ; \delta_{\mathrm{H}} 3.47(\mathrm{~d}, J=14.4 \mathrm{~Hz}), 3.54(\mathrm{~d}, J=14.4 \mathrm{~Hz}), \delta_{\mathrm{C}}$ $38.8]$, two oxygenated quaternary carbons $\left(\delta_{\mathrm{C}} 72.4,86.0\right)$, an oxygenated methine $\left[\delta_{\mathrm{H}} 4.49(\mathrm{t}, J=8.4 \mathrm{~Hz}), \delta_{\mathrm{C}} 89.1\right]$, and a carbomethoxy group $\left(\delta_{\mathrm{H}} 3.76 \mathrm{~s}, \delta_{\mathrm{C}} 53.6,169.8\right)$. The ${ }^{1} \mathrm{H}$ - and ${ }^{13} \mathrm{C}-\mathrm{NMR}$ data of $\mathbf{1}$ were closely related to those of butyrolactone I, but with differences evident in the region of side chain unit $\left(\mathrm{C}-7^{\prime \prime}\right.$ to $\left.\mathrm{C}-11^{\prime \prime}\right)$. Observed HMBC correlations from $\mathrm{Me}-10^{\prime \prime}$ to $\mathrm{C}-8^{\prime \prime}$ and $\mathrm{C}-9^{\prime \prime}$, from Me- $11^{\prime \prime}$ to $\mathrm{C}-8^{\prime \prime}$ and $\mathrm{C}$ $9^{\prime \prime}$, and from $\mathrm{H}_{2}-7^{\prime \prime}$ to $\mathrm{C}-8^{\prime \prime}$ were indicative of the presence of a dihydroxyl group at $\mathrm{C}-8^{\prime \prime}$ and $\mathrm{C}-9^{\prime \prime}$ in $\mathbf{1}$ instead of the $\Delta^{8^{\prime \prime}}, 9^{\prime \prime}$ double bond for butyrolactone I. The absolute stereochemistry at $\mathrm{C}-8^{\prime \prime}$ of $\mathbf{1}$ was assigned by application of the modified Mosher's method. ${ }^{9,10)}$ The difference in chemical shift values $\left(\Delta \delta=\delta_{S}-\delta_{R}\right)$ for its $\alpha$-methoxy- $\alpha$-(trifluoromethyl)phenylacetic acid (MTPA) esters, $\mathbf{1} \mathbf{a}$ and $\mathbf{1 b}$, indicated the $S$-configuration at C-8" (Fig. 2).

As the co-metabolite, butyrolactone I was determined to have the $4 R$-confiugration by comparison of specific rotation data, $[\alpha]_{\mathrm{D}}+84.32$, with the previously reported result. ${ }^{6}$ Therefore the stereochemistry at C-4 of 1 could also be deduced to be $4 R$ based on biosynthetic grounds and similarity
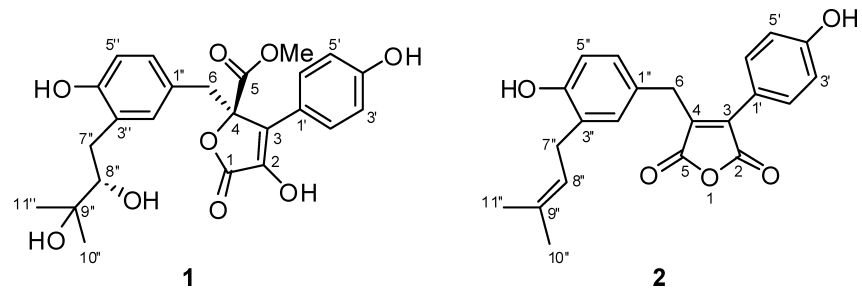

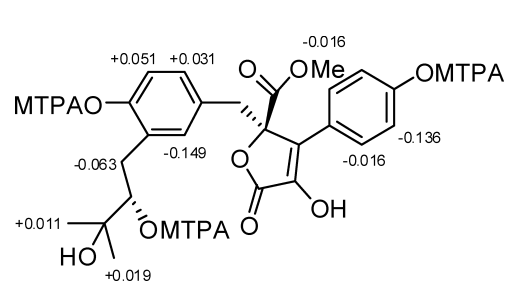

Fig. 2. $\Delta \delta$ Values $\left(\delta_{S}-\delta_{R}\right)$ of the MTPA Esters $\mathbf{1 a}$ and $\mathbf{1 b}$

Fig. 1. Structures of Compounds $\mathbf{1}$ and $\mathbf{2}$ 
of the specific rotation, $[\alpha]_{\mathrm{D}}+40$. In addition, compound $\mathbf{1}$ was treated with $\mathrm{NaIO}_{4}$ to yield the corresponding aldehyde to remove another chiral center at $\mathrm{C}-8^{\prime \prime}$, but one of the products obtained was butyrolactone $I V{ }^{7}{ }^{7}$ not the desired aldehyde. However, this helped to confirm the $4 R$-configuration at $\mathrm{C}-4$ of 1 . The most plausible biosynthetic pathway for the formation of compound $\mathbf{1}$ from butyrolactone $\mathrm{I}$ is the epoxi-

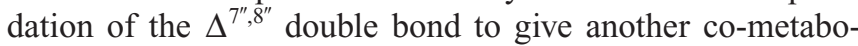
lite, butyrolactone III, followed by ring-opening with water, as shown in Chart 1.

Asperterone (2) was isolated as a yellow gum. The molecular formula $\mathrm{C}_{22} \mathrm{H}_{20} \mathrm{O}_{5}$ was established on the basis of the $[\mathrm{M}+\mathrm{Na}]^{+}$peak at $\mathrm{m} / \mathrm{z} 387.1210($ Calcd 387.1208$)$ in the HRESI-MS, implying 13 degrees of unsaturation. The NMR spectrum of $\mathbf{2}$ (Table 1) displayed a similar signal pattern to those of butyrolactone I for a para-disubstituted benzene ring, a trisubstituted benzene ring with an isopentenyl unit at

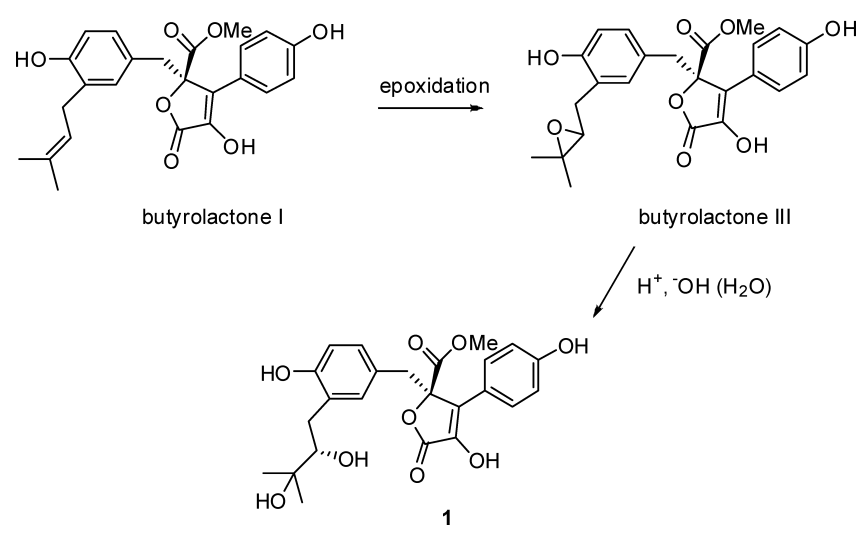

Chart 1. Proposed Biosynthetic Pathway of $\mathbf{1}$
C-3", except for the absence of the carbomethoxy moiety and the presence of an additional ester carbonyl group. The existence of the furan-3-en-2,5-dione at the central core was corroborated by $\mathrm{HMBC}$ correlations from $\mathrm{H}-2^{\prime}$ to $\mathrm{C}-3$, from $\mathrm{H}_{2}$ 6 to both ester carbonyl carbons $(\mathrm{C}-2, \mathrm{C}-5)$ at $\delta_{\mathrm{C}} 165.1$ and 166.1, and from $\mathrm{H}_{2}-6$ to $\Delta^{3,4}$ olefinic carbons, which were considerably deshielded to resonate at $\delta_{\mathrm{C}} 139.7$ and 137.6, respectively. This suggests that each of these olefinic carbons should be connected to the ester carbonyls. In addition, two aromatic rings, an isopentenyl group, two carbonyls, and a double bond account for a total of 12 unsaturation units, and thus the two ester groups must be connected through an oxygen atom to form a furandione ring, consistent with another unsaturation remaining. Therefore the structure of $\mathbf{2}$ was established as shown. This compound gradually decomposed in $\mathrm{CDCl}_{3}$.

Compounds $\mathbf{1}$ and $\mathbf{2}$ were tested for their antibacterial activity against five Gram-positive bacteria (Bacillus subtilis, Staphylococcus aureus, Staphylococcus hominis, Staphylococcus epidermidis, and Enterococcus faecalis), and four Gram-negative bacteria (Escherichia coli, Pseudomonas aeruginosa, Proteus vulgaris, and Salmonella typhimurium). Unfortunately, both compounds were inactive against all bacterial strains tested (minimum inhibitory concentration (MIC) $>256 \mu \mathrm{g} / \mathrm{ml}$ ).

\section{Experimental}

General Experimental Procedures Optical rotations were measured on a Perkin-Elmer 341 polarimeter using a sodium lamp at wavelength of $589 \mathrm{~nm}$, and UV data were recorded on a Shimadzu UV-160 spectrophotometer. IR spectra were recorded on a Bruker vector22 Fourier-transform infrared spectrophotometer. The NMR spectra were recorded on a Varian YH400 spectrometer at $400 \mathrm{MHz}$ for ${ }^{1} \mathrm{H}-\mathrm{NMR}$ and at $100 \mathrm{MHz}$ for ${ }^{13} \mathrm{C}-$ NMR using tetramethylsilane as the internal standard. HR-ESI-MS were obtained using a Bruker micrOTOF mass spectrometer.

Table 1. NMR Spectroscopic Data (400 MHz for ${ }^{1} \mathrm{H}-\mathrm{NMR}$ and $100 \mathrm{MHz}$ for ${ }^{13} \mathrm{C}-\mathrm{NMR}, \mathrm{CDCl}_{3}$ ) for Aspernolide D (1) and Asperterone (2)

\begin{tabular}{|c|c|c|c|c|c|c|}
\hline \multirow{2}{*}{ Position } & \multicolumn{3}{|c|}{$\mathbf{1}^{a)}$} & \multicolumn{3}{|c|}{$\mathbf{2}^{b)}$} \\
\hline & $\delta_{\mathrm{H}}(J$ in $\mathrm{Hz})$ & $\delta_{\mathrm{C}}$, mult & HMBC correlations & $\delta_{\mathrm{H}}(J$ in $\mathrm{Hz})$ & $\delta_{\mathrm{C}}$, mult & HMBC correlations \\
\hline 1 & & $169.4, \mathrm{qC}$ & & & & \\
\hline 2 & & $137.4, \mathrm{qC}$ & & & $165.1, \mathrm{qC}$ & \\
\hline 3 & & $128.2, \mathrm{qC}$ & & & $139.7, \mathrm{qC}$ & \\
\hline 4 & & $86.0, \mathrm{qC}$ & & & 137.6, qC & \\
\hline 5 & & $169.8, \mathrm{qC}$ & & & $166.1, \mathrm{qC}$ & \\
\hline \multirow[t]{2}{*}{6} & $3.54 \mathrm{~d}(14.4)$ & $38.8, \mathrm{CH}_{2}$ & $2,3,4,1^{\prime \prime}, 2^{\prime \prime}, 6^{\prime \prime}$ & $3.94 \mathrm{~s}$ & $28.8, \mathrm{CH}_{2}$ & $2,3,4,5,1^{\prime \prime}, 2^{\prime \prime}, 6^{\prime \prime}$ \\
\hline & $3.47 \mathrm{~d}(14.4)$ & & $2,3,4,1^{\prime \prime}, 2^{\prime \prime}, 6^{\prime \prime}$ & & & \\
\hline $1^{\prime}$ & & $122.1, \mathrm{qC}$ & & $118.7, \mathrm{qC}$ & & \\
\hline $2^{\prime}\left(6^{\prime}\right)$ & $7.60 \mathrm{~d}(8.8)$ & $129.5, \mathrm{CH}$ & $3,1^{\prime}, 3^{\prime}, 6^{\prime}\left(2^{\prime}\right)$ & $7.64 \mathrm{~d}(8.7)$ & 131.1, CH & $3,1^{\prime}, 4^{\prime}, 6^{\prime}\left(2^{\prime}\right)$ \\
\hline $3^{\prime}\left(5^{\prime}\right)$ & $6.90 \mathrm{~d}(8.8)$ & $116.1, \mathrm{CH}$ & $1^{\prime}, 2^{\prime}, 4^{\prime}, 5^{\prime}\left(3^{\prime}\right)$ & $6.99 \mathrm{~d}(8.7)$ & $115.3, \mathrm{CH}$ & $2^{\prime}, 4^{\prime}, 5^{\prime}\left(3^{\prime}\right)$ \\
\hline $4^{\prime}$ & & $156.8, \mathrm{qC}$ & & & $159.5, \mathrm{qC}$ & \\
\hline $1^{\prime \prime}$ & & $124.7, \mathrm{gC}$ & & & $126.5, \mathrm{qC}$ & \\
\hline $2^{\prime \prime}$ & $6.64 \mathrm{~s}$ & $126.9, \mathrm{CH}$ & $6,6^{\prime \prime}, 7^{\prime \prime}$ & $7.00 \mathrm{~s}$ & 129.1, CH & $4^{\prime \prime}$ \\
\hline $3^{\prime \prime}$ & & $126.7, \mathrm{qC}$ & & & $127.8, \mathrm{qC}$ & \\
\hline $4^{\prime \prime}$ & & $158.7, \mathrm{qC}$ & & & $153.4, \mathrm{qC}$ & \\
\hline $5^{\prime \prime}$ & $6.46 \mathrm{~d}(8.4)$ & $108.5, \mathrm{CH}$ & $4^{\prime \prime}$ & $6.75 \mathrm{~d}(8.2)$ & 114.7, CH & $4^{\prime \prime}$ \\
\hline $6^{\prime \prime}$ & $6.54 \mathrm{~d}(8.4)$ & $130.1, \mathrm{CH}$ & $6,2^{\prime \prime}, 4^{\prime \prime}$ & $6.92 \mathrm{~d}(8.2)$ & 126.1, CH & $6,5^{\prime \prime}$ \\
\hline $7^{\prime \prime}$ & $2.97 \mathrm{~m}$ & $30.5, \mathrm{CH}_{2}$ & $4^{\prime \prime}, 2^{\prime \prime}, 3^{\prime \prime}, 8^{\prime \prime}$ & $3.26 \mathrm{~d}(7.4)$ & $27.5, \mathrm{CH}_{2}$ & $2^{\prime \prime}, 3^{\prime \prime}, 4^{\prime \prime}, 8^{\prime \prime}$ \\
\hline $8^{\prime \prime}$ & $4.49 \mathrm{t}(8.4)$ & $89.1, \mathrm{CH}$ & $9^{\prime \prime}, 10^{\prime \prime}, 11^{\prime \prime}$ & $5.27 \mathrm{t}(7.4)$ & $122.1, \mathrm{CH}$ & $9^{\prime \prime}, 10^{\prime \prime}, 11^{\prime \prime}$ \\
\hline $9^{\prime \prime}$ & & $72.4, \mathrm{qC}$ & & & $131.2, \mathrm{qC}$ & \\
\hline $10^{\prime \prime}$ & $1.27 \mathrm{~s}$ & $25.8, \mathrm{CH}_{3}$ & $8^{\prime \prime}, 9^{\prime \prime}, 11^{\prime \prime}$ & $1.69 \mathrm{~s}$ & $24.5, \mathrm{CH}_{3}$ & $8^{\prime \prime}, 9^{\prime \prime}, 11^{\prime \prime}$ \\
\hline $11^{\prime \prime}$ & $1.14 \mathrm{~s}$ & $23.9, \mathrm{CH}_{3}$ & $8^{\prime \prime}, 9^{\prime \prime}, 10^{\prime \prime}$ & $1.66 \mathrm{~s}$ & $16.4, \mathrm{CH}_{3}$ & $8^{\prime \prime}, 9^{\prime \prime}, 10^{\prime \prime}$ \\
\hline 5-OMe & $3.76 \mathrm{~s}$ & $53.6, \mathrm{CH}_{3}$ & 5 & & & \\
\hline $4^{\prime}-\mathrm{OH}$ & & & & $9.15 \mathrm{~s}$ & & $4^{\prime}, 6^{\prime}$ \\
\hline $4^{\prime \prime}-\mathrm{OH}$ & & & & $8.20 \mathrm{~s}$ & & $4^{\prime \prime}$ \\
\hline
\end{tabular}

a) Recorded in $\mathrm{CDCl}_{3}$. b) Recorded in acetone- $d_{6}$. 
Fungal Material The fungus $A$. terreus $\mathrm{RCBC} 1002$ was isolated from the leaves of $M$. siamensis collected from Rayong province, Thailand, in May 2008. This fungus was identified as A. terreus by one of authors (N.B.) based on sequence (GenBank Accession number GU362937) analysis of the $18 \mathrm{~S}$ ribosomal DNA and internal transcribed spacer genes.

The isolate was subcultured on potato dextrose agar plates at $25^{\circ} \mathrm{C}$ for $7 \mathrm{~d}$. Agar plugs were used to inoculate 1000 -ml Erlenmeyer flasks, each containing $200 \mathrm{ml}$ of medium (corn steep liquor $1 \mathrm{~g}$, mannitol $10 \mathrm{~g}$, maltose $10 \mathrm{~g}$, glucose $5 \mathrm{~g}$, monosodium glutamate $10 \mathrm{~g}, \mathrm{KH}_{2} \mathrm{PO}_{4} 0.5 \mathrm{~g}, \mathrm{MgSO}_{4} \cdot 7 \mathrm{H}_{2} \mathrm{O}$ $0.3 \mathrm{~g}$, yeast extract $3 \mathrm{~g}$ per liter). Flask cultures were incubated at $30^{\circ} \mathrm{C}$ under static conditions for $21 \mathrm{~d}$.

Extraction and Isolation Ten-liter cultures were filtered, and the culture broth was extracted with EtOAc $(\times 3)$. The combined organic layer was concentrated to afford the crude extract $(12.60 \mathrm{~g})$. The extract was fractionated by Sephadex LH20 column chromatography eluted with $\mathrm{MeOH}$ to yield six fractions $(\mathrm{I}-\mathrm{VI})$. Fraction III was chromatographed on a silica gel column eluted with acetone-benzene $(1: 3)$ to give butyrolactone I $(2.76 \mathrm{~g})$, butyrolactone II $(1.64 \mathrm{~g})$, aspernolide B $(346.0 \mathrm{mg})$, and 10 subfractions (III-1 to III-10). Subfraction III-1 was subjected to flash silica gel column chromatography (acetone-benzene, $1: 9$ ) and further purified on a silica gel column (hexane-acetone, $3: 1)$ to afford $2(8.2 \mathrm{mg}$ ), whereas purification of subfraction III-7 by flash column chromatography eluted with $\mathrm{MeOH}-$ $\mathrm{CHCl}_{3}(1: 30)$ gave $1(16.2 \mathrm{mg})$ and butyrolactone III $(45.5 \mathrm{mg})$. Fraction III-8 was rechromatographed on a silica gel column (acetone-benzene, $1: 2$ ) followed by preparative TLC $\left(\mathrm{MeOH}-\mathrm{CH}_{2} \mathrm{Cl}_{2}, 5: 95\right)$ to yield butyrolactone IV (9.2 mg).

Aspernolide D (1): Light yellow gum; $[\alpha]_{\mathrm{D}}^{20}+40(c=0.1, \mathrm{MeOH})$; UV $(\mathrm{MeOH}) \lambda_{\max }(\log \varepsilon) 290(4.14) \mathrm{nm} ; \mathrm{IR}(\mathrm{KBr}) v_{\max } 3443,2956,1697,1633$, $1620,1513,1439,1262,1108,939 \mathrm{~cm}^{-1} ;{ }^{1} \mathrm{H}-$ and ${ }^{13} \mathrm{C}-\mathrm{NMR}$ data $\left(\mathrm{CDCl}_{3}\right)$, see Table 1; HR-ESI-MS, $m / z 481.1472$ (Calcd for $\mathrm{C}_{24} \mathrm{H}_{26} \mathrm{O}_{9} \mathrm{Na}, 481.1475$ ).

Asperterone (2): Yellow gum; UV (MeOH) $\lambda_{\text {max }}(\log \varepsilon) 205$ (3.97) nm; IR $(\mathrm{KBr}) v_{\max } 3443,2926,1730,1660,1604,1511,1439,1238,1170$, $1114 \mathrm{~cm}^{-1}$; ${ }^{1} \mathrm{H}$ - and ${ }^{13} \mathrm{C}$-NMR data $\left(\mathrm{CDCl}_{3}\right)$, see Table 1 ; HR-ESI-MS, $m / z$ 387.1210 (Calcd for $\mathrm{C}_{22} \mathrm{H}_{20} \mathrm{O}_{5} \mathrm{Na}, 387.1208$ ).

Preparation of MTPA Ester Derivatives of $\mathbf{1}$ To a solution of $\mathbf{1}$ $(3.0 \mathrm{mg})$ in pyridine $(0.3 \mathrm{ml})$ was added $(R)$-MTPA $\mathrm{Cl}(20 \mu \mathrm{l}))^{9,10)}$ The reaction mixture was stirred at room temperature overnight. The mixture was diluted with EtOAc and washed with $\mathrm{H}_{2} \mathrm{O}$ and $1 \mathrm{M} \mathrm{NaHCO}_{3}$, and the organic layer was concentrated under reduced pressure. The residue was purified on a short silica gel column $\left(\mathrm{MeOH}-\mathrm{CH}_{2} \mathrm{Cl}_{2}\right)$ to obtain the $(S)$-MTPA ester 1a $(1.8 \mathrm{mg}):{ }^{1} \mathrm{H}-\mathrm{NMR}$ data $\left(\mathrm{CDCl}_{3}, 400 \mathrm{MHz}\right) \delta: 7.56\left(2 \mathrm{H}, \mathrm{d}, J=8.8 \mathrm{~Hz}, \mathrm{H}-2^{\prime}\right.$, H-6' $), 6.86\left(2 \mathrm{H}, \mathrm{d}, J=8.8 \mathrm{~Hz}, \mathrm{H}-3^{\prime}, \mathrm{H}-5^{\prime}\right), 6.60$ (s, H-2"), $6.50(1 \mathrm{H}, \mathrm{d}$ $\left.J=8.4 \mathrm{~Hz}, \mathrm{H}-6^{\prime \prime}\right), 6.45\left(1 \mathrm{H}, \mathrm{d}, J=8.4 \mathrm{~Hz}, \mathrm{H}-5^{\prime \prime}\right), 4.46(1 \mathrm{H}, \mathrm{t}, J=8.4 \mathrm{~Hz}, \mathrm{H}-$ $\left.8^{\prime \prime}\right), 3.72(\mathrm{~s}, 5-\mathrm{OMe}), 3.50(1 \mathrm{H}, \mathrm{d}, J=14.4 \mathrm{~Hz}, \mathrm{H}-6 \mathrm{a}), 3.42(1 \mathrm{H}, \mathrm{d}$, $J=14.4 \mathrm{~Hz}, \mathrm{H}-6 \mathrm{~b}), 2.94\left(2 \mathrm{H}, \mathrm{m}, \mathrm{H}_{2}-7^{\prime \prime}\right), 1.24$ (3H, s, Me-10"), 1.20 (3H, s, Me-11").

Similarly, the reaction mixture of $1(3.0 \mathrm{mg}),(S)$-MTPA Cl $(20 \mu \mathrm{l})$ and pyridine $(0.3 \mathrm{ml})$ was processed as described above for $\mathbf{1 a}$ to afford $\mathbf{1 b}$ (1.5 mg): ${ }^{1} \mathrm{H}-\mathrm{NMR}$ data $\left(\mathrm{CDCl}_{3}, 400 \mathrm{MHz}\right) \delta: 7.58\left(2 \mathrm{H}, \mathrm{d}, J=9.2 \mathrm{~Hz}, \mathrm{H}-2{ }^{\prime}\right.$, H-6') 6.99 (2H, d, J=9.2 Hz, H-3', H-5'), 6.75 (s, H-2"), 6.47 (1H, d, $\left.J=8.4 \mathrm{~Hz}, \mathrm{H}-6^{\prime \prime}\right), 6.40\left(1 \mathrm{H}, \mathrm{d}, J=8.4 \mathrm{~Hz}, \mathrm{H}-5^{\prime \prime}\right), 4.51(1 \mathrm{H}, \mathrm{t}, J=9.6 \mathrm{~Hz}, \mathrm{H}-$ $\left.8^{\prime \prime}\right), 3.74$ (s, 5-OMe), $3.62(1 \mathrm{H}, \mathrm{d}, J=14.8 \mathrm{~Hz}, \mathrm{H}-6 \mathrm{a}), 3.58(1 \mathrm{H}, \mathrm{d}$,
$J=14.8 \mathrm{~Hz}, \mathrm{H}-6 \mathrm{~b}), 3.00\left(2 \mathrm{H}, \mathrm{m}, \mathrm{H}_{2}-7^{\prime \prime}\right), 1.22\left(3 \mathrm{H}, \mathrm{s}, \mathrm{Me}-10^{\prime \prime}\right), 1.19(3 \mathrm{H}, \mathrm{s}$, Me-11").

Biological Assays A broth microdilution method was used to determine the MIC according to the NCCLS protocol. ${ }^{11,12)}$ Five reference Gram-positive bacteria, B. subtilis ATCC 6633, S. aureus ATCC 25923, S. hominis ATCC 27844, S. epidermidis ATCC 12228 and E. faecalis ATCC 29212; and four Gram-negative bacteria, E. coli ATCC 35218, P. aeruginosa ATCC 27853, P. vulgaris ATCC 13315 and S. typhimurium ATCC 13311 were used. All tests were performed in Mueller-Hinton broth. Serial doubling dilutions of the compound, prepared in a 96-well microtiter plate, ranged from 0.5 to $256 \mu \mathrm{g} / \mathrm{ml}$. The final concentration of each strain was adjusted to $5 \times 10^{5}$ colony forming unit $(\mathrm{CFU}) / \mathrm{ml}$. The minimum inhibitory concentration (MIC) was defined as the lowest concentration of the compound at which the microorganism did not demonstrate visible growth as determined by turbidity.

Acknowledgments Financial support from the 90th Anniversary of Chulalongkorn University Fund (Ratchadaphisek Somphot Endowment Fund) and National Science and Technology Development Agency, Ministry of Science and Technology, is gratefully acknowledged. We also thank the Center for Petroleum, Petrochemicals, and Advanced Materials, Chulalongkorn University, for partial support. Finally, we are grateful for the research fund from the Thai Government Stimulus Package 2 (TKK25555), under the Project for Establishment of a Comprehensive Center for Innovative Food, Health Products and Agriculture.

\section{References}

1) Schulz B., Boyle C., Draeger S., Rommert A.-K., Krohn K., Mycol. Res., 106, 966-1004 (2002).

2) Strobel G. A., Microbes Infect., 5, 535-544 (2003).

3) Wijeratne E. M. K., Paranagama P. A., Marron M. T., Gunatilaka M. K., Arnold A. E., Gunatilaka A. A. L., J. Nat. Prod., 71, 218-222 (2008).

4) Kjer J., Wray V., Edrada-Ebel R., Pretsch A., Lin W., Proksch P., J. Nat. Prod., 72, 2053-2057 (2009).

5) Isaka M., Palasarn S., Lapanun S., Chanthaket R., Noonyuen N., Lumyong S., J. Nat. Prod., 72, 1720-1722 (2009).

6) Kiriyama N., Nitta K., Sakaguchi Y., Taguchi Y., Yamamoto Y., Chem. Pharm. Bull., 25, 2593-2601 (1977).

7) Rao K. V., Sadhukhan A. K., Veerender M., Ravikumar V., Mohan E. V. S., Dhanvantri S. D., Sitaramkumar M., Moses Babu J., Vyas K., Om Reddy G., Chem. Pharm. Bull., 48, 559-562 (2000).

8) Parvatkar R. R., D’Souza C., Tripathi A., Naik C. G., Phytochemistry, 70, 128-132 (2009).

9) Dale J. A., Mosher H. S., J. Am. Chem. Soc., 95, 512-519 (1973).

10) Ohtani I., Kysumi T., Kashman Y., Kakisawa H., J. Am. Chem. Soc., 113, 4092-4096 (1991).

11) Pudhom K., Sommit D., Nuclear P., Ngamrojanavanich N., Petsom A., J. Nat. Prod., 72, 2188-2191 (2009).

12) National Committee for Clinical Laboratory Standards, "Performance Standards for Antimicrobial Susceptibility Testing," Proceedings of the Ninth International Supplement, M100-S9, Wayne, PA, 1999. 